Ecke, Peter and Hall, Christopher J

ORCID: https://orcid.org/0000-0001-9038-1238 (2021) Bilingual Aspects of the Ontogenesis Model: Parasitic Connections at all Levels of Representation? Bilingualism: Language and Cognition. pp. 1-2.

Downloaded from: http://ray.yorksj.ac.uk/id/eprint/5523/

The version presented here may differ from the published version or version of record. If you intend to cite from the work you are advised to consult the publisher's version: http://dx.doi.org/10.1017/S1366728921000675

Research at York St John (RaY) is an institutional repository. It supports the principles of open access by making the research outputs of the University available in digital form. Copyright of the items stored in RaY reside with the authors and/or other copyright owners. Users may access full text items free of charge, and may download a copy for private study or non-commercial research. For further reuse terms, see licence terms governing individual outputs. Institutional Repository Policy Statement

\title{
RaY
}

Research at the University of York St John

For more information please contact RaY at ray@yorksj.ac.uk 


\section{Bilingual Aspects of the Ontogenesis Model: Parasitic Connections at all Levels of Representation?}

Bordag, Gor and Opitz (2021) (henceforth BGO) deserve credit for having developed the (to-date) most comprehensive model of $L 2$ lexical acquisition, by building on a wide range of studies on perception and comprehension of $L 2$ lexis. However, although they cite numerous studies that point to the importance of cross-linguistic influence (CLI) for L2 lexical processing and development, they deliberately eschew the bilingual focus of other models. Since our work has focused on this aspect, here we point to research into CLI that, we believe, could help explain key concepts of the Ontogenesis Model (OM), especially the "fuzziness" of lexical representations, mappings, and networks.

Like the OM, the Parasitic Model of L2 and L3 vocabulary acquisition (PM) (Hall \& Ecke, 2003) "makes assumptions about the development of individual lexical items, not the lexicon as a whole. Individual lexical items will be at different acquisition stages over time, displaying different kinds of configurations and different degrees of automatization in their processing" (Ecke \& Hall, 2014, p. 362). Also like the OM, the PM focuses (in BGO's words) “primarily on the initial stages of acquisition in the phonological, orthographic and semantic domains and the corresponding mappings" (p. 2); but it includes a grammatical frame component, a representational level that the OM in its present form does not address.

The detection and use of similarity between new and known information is central to the PM. We have demonstrated that learners make use of prior representations from L1, other L2s (OM's "InterNetwork") and from within the target L2 or L3 (OM's "IntraNetwork"). We have analyzed lexical confusions in L2 and L3 production and argued that many are the result of learners using a parasitic strategy: learners detect similarity between new and already represented forms and use the latter to anchor new representations into "the existing lexical network with the least possible redundancy and as rapidly as possible in order to make them accessible for communication" (Hall \& Ecke, 2003, p. 77). Like L1 word learning (Aitchison \& Straf, 1981), L2 word forms are acquired incrementally; what is acquired first (and fast) are salient attributes of the new word form and those that are exploited from existing ones (Ecke, 2001). In these cases, just as BGO claim for links to existing semantic representations, "the ontogenetic curve [...] steeply rises" (p. 13). But, like grammatical frames (Hall \& Reyes Duran, 2009) and meaning representations (Jiang, 2000), incomplete or deviant forms and their access routes can fossilize and their refinement and revision can take as much time or longer than the development of meaning representations. 
We studied lexical form confusions through errors and associations produced during extended word search in tip-of-the-tongue (TOT) states (Ecke \& Garrett, 1998; Ecke, 2001) and like BGO found that most came from within the target L2 or L3 (OM's IntraNetwork). We discussed the "particular form sensitivity of speakers at early stages of vocabulary acquisition" and argued that "form-focused processing is a general temporal disposition which is necessary for the learner to integrate new words (no matter whether of $L 1, L 2$ or L3) into the phonological store of the lexicon (Ecke \& Garrett, 1998, p. 171). Whereas the automatized retrieval of stable (L1) representations can be triggered by only a few salient form attributes (first letter, number of syllables), access to unstable forms requires the co-activation or sharing of host representations that are used as mediators between form-frame-meaning mappings. L2 learners rely on a greater number of form attributes, including those similar to known representations. This L1-L2 co-activation, we believe, leads to what BGO call confusions and contributes to the overall "fuzziness" of new representations and mappings. BGO do acknowledge that $L 1$ cognates and false cognates contribute to $L 2$ representations, but the PM claims a more central role for form similarity. In a study with pseudocognates, Hall (2002) demonstrated that shared form automatically leads to assumptions of shared meaning. Later we showed that it also determines assumptions about frame representations (Hall et al., 2009).

Although we have stressed the importance of $\mathrm{CLI}$ in lexical development, we actually appreciate that the OM goes beyond explaining lexical acquisition only in terms of L1 transfer and changes of L1-L2 mappings. We also like the idea of using ontogenetic curves to capture the degree of acquisition of specific domains. We are confident that future versions of the OM will add assumptions about the development of grammatical frame representations, given that $\mathrm{OM}$ authors have demonstrated important effects they have on lexical processing (Bordag, Opitz \& Pechmann, 2006). But a comprehensive model of vocabulary acquisition will not get around acknowledging the pervasiveness of $\mathrm{CLI}$ from $\mathrm{L} 1$ and (other) previously acquired $\mathrm{L} 2$ representations. It is a main contributing factor to the fuzziness of lexical representations at form, frame, and meaning levels. BGO will in the end have to admit that their model truly IS a bilingual model of lexical development.

\section{References}

Aitchison, J and Straf, M (1981) Lexical storage and retrieval: A developing skill? Linguistics 19, 751795.

Bordag, D, Gor, K and Opitz, A (2021) Ontogenesis Model of the L2 Lexical Representation. Bilingualism: Language and Cognition 1-17. https://doi.org/10.1017/S1366728921000250 Bordag, D, Opitz, A and Pechmann, T (2006) Gender processing in first and second languages: The 
role of noun termination. Journal of Experimental Psychology: Learning, Memory, and Cognition 32(5), 1090-1101. https//doi.org/10.1037/0278-7393.32.5.1090

Ecke, P (2001) Lexical retrieval in a third language: Evidence from errors and tip-of-the-tongue states. In Cenoz, J, Hufeisen, B and Jessner, U (Eds.), Cross-linguistic Aspects of $\angle 3$ Acquisition: Psycholinguistic Perspectives. Clevedon: Multilingual Matters pp. 90-114. https://doi.org/10.21832/9781853595509

Ecke, P and Garrett, MF (1998) Lexical retrieval stages of momentarily inaccessible foreign language words. Ilha do Desterro 35, 157-183.

Ecke, P and Hall, CJ (2014) The Parasitic Model of L2 and L3 vocabulary acquisition: Evidence from naturalistic and experimental studies. Fórum Linguístico 11(3), 360-372. https://doi.org/10.5007/1984-8412.2014v11n3p360

Hall, CJ (2002) The automatic cognate form assumption: Evidence for the parasitic model of vocabulary development. International Review of Applied Linguistics in Language Teaching 40(2), 69-87. https://doi.org/10.1515/iral.2002.008

Hall, CJ and Ecke, P (2003) Parasitism as a default mechanism in L3 vocabulary acquisition. In Cenoz, J, Hufeisen, B and Jessner, U (Eds.), The Multilingual Lexicon. Dordrecht: Kluwer Academic Publishers pp. 71-85. https://doi.org/10.1007/978-0-306-48367-7_6

Hall, CJ, Newbrand, D, Ecke, P, Sperr, U, Marchand, V and Hayes, L (2009) Learners' implicit assumptions about syntactic frames in new L3 words: The role of cognates, typological proximity, and L2 status. Language Learning 59(1), 153-202. https://doi.org/10.1111/j.1467-9922.2009.00503.x

Hall, CJ and Reyes Duran, A (2009) Cross-linguistic influence in L2 verb frames: the effects of word familiarity and language proficiency. In Benati, AG (Ed.), Issues in Language Proficiency. London: Continuum pp. 24-44.

Jiang, N (2000). Lexical representation and development in a second language. Applied Linguistics $21,47-77$. 